GLOBAL JOURNAL OF EDUCATIONAL RESEARCH VOL 19, 2020: 9-14

COPYRIGHT@ BACHUDO SCIENCE CO. LTD PRINTED IN NIGERIA. ISSN 1596-6224 www.globaljournalseries.com; Info@globaljournalseries.com

\title{
PRE-SERVICE BIOLOGY TEACHERS' PERCEPTION OF GLOBAL WARMING, GREENHOUSE EFFECT AND OZONE LAYER DEPLETION IN LAGOS STATE UNIVERSITY
}

BENJAMIN A. ETOBRO

(Received 8, November 2019; Revision Accepted 18, December 2019)

\begin{abstract}
The study examined the crux about global warming, greenhouse effect and ozone layer depletion among pre-service biology teachers. A survey questionnaire adapted from Kalipit, Yener \& Ozkadif (2009); Rye, Ruba \& Wiesenmayer (1997) and Boyes, Chambers \& Stanisstreet (1995) was administered to 65 pre-service Biology teachers purposively selected from the Department of Science and Technology Education, Lagos State University, Lagos. This was to determine the pre-service biology teachers' perceptions about global warming, greenhouse effect and ozone layer depletion. Data collected were analyzed using descriptive statistics. Results showed that pre-service Biology teachers had misconceptions that the results of thinning of ozone layer will increase greenhouse effect and the function of ozone layer is to protect the earth against excessive heat. Furthermore, majority of the preservice biology teachers had misconceptions on global warming, ozone layer depletion and greenhouse effect. It is imperative, therefore to proffer solutions to these misconceptions held by the pre-service teachers by ensuring that instructors and instructional materials emphasize the importance of these concepts to life ensuring that students have adequate knowledge about the concepts as well as ways of tackling these challenges.
\end{abstract}

KEYWORD: Global warming, greenhouse effect, ozone layer depletion, pre-service biology teachers, misconceptions.

\section{INTRODUCTION}

The advent of industrialization since industrial revolution that began in the 1950s, gave rise to environmental problems such as harmful wastes. During this period, environmental problems were associated to water, air and soil pollution, especially in industrial sites. Industrialization brought about different hazardous environmental problems such as ozone layer depletion, increase in greenhouse effect, global warming as well as degradation of some natural resources.
Kalipit et al (2009) stressed that events such as climate changes, melting glaciers and drought resulting from global warming show clear enough the danger our world will have to face in the next future. Increased ecological disturbance as a result of human activities increase the complexity, severity and intensity of environmental challenges. Consequently developing nations such as Nigeria would perhaps experience complex environmental problems such as flooding, over-population, deforestation, erosion, industrialization, and solid

Benjamin A. Etobro, Department of Science and Technology Education Faculty of Education, Lagos State University, Ojo 
waste disposal.

There have been concerns over climatic change in recent years as a result of human activities such as deforestation and burning of fossil fuels. Deforestation has led to loss of biodiversity and enhanced the greenhouse effect. Burning of fuels has lead to the release of gases known as the greenhouse gases. The earth surface is heated up by the absorbed solar energy. The activities of these gases have lead to rise in temperature of the earth planet with the resultant effect of global warming. Riphah (2015) stressed that the concentrations of carbon dioxide, methane, and nitrous oxide are all known to be increasing in recent years, which has led to the increase in significant quantities of greenhouse gases.

Global warming begins when sunlight reaches the Earth, the clouds, atmospheric particles, reflective ground surfaces and surface of oceans then reflect back about $30 \%$ of sunlight back into the space, whilst the remaining $70 \%$ is absorbed by oceans, air and land. This consequently heats up the surface of the planet and atmosphere, making life feasible. According to Riphah (2015) as the earth warms up, this solar energy is radiated by thermal radiation and infrared rays, propagating directly out to space thereby cooling the Earth. It is worthy of note that some of the reflected solar energy is re-absorbed by Carbon (IV) oxide, ozone, methane water vapours and in some cases compounds containing chlorine and bromine, this is however radiated back to the earth surface. The re-absorption process by these greenhouse gases has great impact on the Earth's average surface temperature without which the earth surface would have been very cold. But it becomes worrisome when the concentration of these greenhouse gases increased as a result of human activities at an exponential rate since the last two decades. The greenhouse gases perhaps were in balance before two centuries ago. Goel and Bhatt (2012) expressed feared that, at the present rate of increase of greenhouse gases, the natural balance will be upset. They stated further that the formation of fossil fuels took millions of years, but it takes only a few minutes for them to burn, releasing large quantities of carbon (IV) oxide into the air.

Carbon (IV) oxide and other greenhouse gases absorb infrared radiation and prevent it from reflecting back into the outer space. This results into regular heating of the earth's atmosphere and surface. Greenhouse gases are the major causes of global warming because when these gases build up in an unprecedented quantity, the radiative balance in the Earth's atmosphere changes. Riphah (2015) concord that the overall effect of these gases warm the Earth's surface and the troposphere (lower atmosphere) because greenhouse gases absorb some of the outgoing radiation of Earth and re-radiate it back towards the surface. This natural process of warming up the Earth's surface and the lower atmosphere is referred to as the greenhouse effect. The combined impact of greenhouse effect and the increasing levels of greenhouse gases, results to global warming. Marc (2015) expressed fear that if global warming continues unrestrained and nothing effective is done to limit this evil; it will cause significant climate change, a rise in sea levels, extreme weather events and other ruthless natural, environmental and social impacts. Naturally greenhouse effect traps some solar energy in such a way that the Earth planet is prevented from reaching freezing temperatures but human activities promote greenhouse effect which leads to global warming.

Another major environmental problem is the thinning of the stratospheric ozone layer. Ozone is a colourless gas found in the upper atmosphere of the earth. Chemically, it is formed when oxygen molecules absorb ultraviolet photons, and undergo a chemical reaction known as photo dissociation or photolysis. In this process, a single molecule of oxygen breaks down into two oxygen molecule of ozone $\left(\mathrm{O}_{3}\right)$. Riphah (2015) stresses that the depletion of the ozone layer is mainly due to the presence of chlorine and bromine gases such as chlorofluorocarbons (CFCs) and halos. The presence of Ultraviolet light leads to dissociation of these gases thereby releasing chlorine atoms which thereafter catalyses atmospheric ozone molecule. These are often in vehicle emissions, bye-products of industrial processes refrigerants, and aerosols. Ozone-depleting substances are relatively stable in the lower atmosphere of the thinning of the stratospheric ozone layer of the Earth, but in the stratosphere, they are exposed to Ultraviolet Radiation (UV) and thus, breaking down to release a free chlorine atom. This free chlorine atom reacts with an ozone molecule $\left(\mathrm{O}_{3}\right)$, and forms chlorine monoxide $(\mathrm{ClO})$, and a molecule of oxygen. Now, $\mathrm{ClO}$ reacts with an ozone molecule to form a chlorine atom, and two molecules of oxygen. The free chlorine molecule again reacts with ozone to form chlorine monoxide. The resultant effect of this continuous process is the depletion of the ozone layer. 
The contributions of humans to greenhouse effect include: burning of natural gas, coal and oil, some farming practices and land-use changes, deforestation and population growth. At national and international levels, conscious awareness on the detrimental effects of environmental problems due to climate change had in past been created. These include technological development, enacting laws as well as punishing people who cause pollution, but these are not alone sufficient to deal with the ever growing environmental problems efficiently. Conscious awareness seems to have been created on the causes, effects and hazards of these environmental factors. The study sought to answer some vital questions on the level of awareness among pre-service biology teachers. This study therefore, was carried out to determine the conception of pre-service biology teachers about global warming, greenhouse effect and ozone layer depletion.

\section{METHODOLOGY}

The study is a survey carried out to find out the perception of pre-service Biology teachers on some issues on climate change. Sixty five (65) pre-service Biology teachers from the Department of Science and Technology Education, Faculty of Education of Lagos State University were purposively selected during the 2016/2017 academic session.

A closed ended questionnaire was employed to collect data for the study to determine the perceptions pre-service science teachers had about greenhouse effect, global warming and ozone layer depletion. The instrument was adapted from Kalipit et al, (2009); Rye, Ruba and Wiesenmayer (1997) and Boyes, Chambers and Stainisstreet (1995). It consisted of thirty statements which were administered on the preservice Biology teachers to determine perceptions they had and the results were analyzed with a- three point Likert scale of Yes,
No or Not Sure options. The instrument was given to two lecturers who are seasoned lecturers of Issues in Science Education to determine its content and face validity. Cronbach alpha coefficient was used to determine its reliability and this was found to be .72 . The preservice Biology teachers completed the questionnaire. The respondents were sensitized on the importance of the study to prevent them from filling the questionnaire without reading through the statements and/or getting the correct answers from the internet. They were also told that it was not an examination to prevent the concomitant test anxiety. The data collected were analyzed with simple percentages.

\section{RESULTS AND FINDINGS}

Table 1 shows that $60 \%$ of the pre-service biology teachers misconceive that increase in greenhouse effect could lead to food poisoning. Furthermore, $48 \%$ of the pre-service biology teachers held the view that reduction in greenhouse effect could be achieved by protecting the diminishing species of plants and animals. Also, $28 \%$ of the pre-service science teachers had the misconception that the increase in the amount of garbage by people would not increase greenhouse effect. $61.4 \%$ of the preservice science teachers misconceived that increase in the amount of acid rains increases greenhouse effect. The pre-service science teachers misconceived the greenhouse effect for concepts of green housing in agriculture. Also the table reveals that $77.4 \%$ and $70 \%$ of the preservice biology teachers respectively had a wrong view that preventing the usage of nuclear bombs will reduce greenhouse effect and that greenhouse effect would increase as a result of waste thrown away from nuclear power stations. From the finding above, pre-service biology teachers had a lot of misconceptions about environmental issues which can probably happen as greenhouse effect increases. 
Table 1: Responses of Pre-Service Teachers to the Statement about Greenhouse effect

\begin{tabular}{|c|c|c|c|c|}
\hline $\mathbf{S} / \mathbf{N}$ & Statement & Yes (\%) & No (\%) & Not Sure (\%) \\
\hline 1 & $\begin{array}{l}\text { When greenhouse effect rises people will be poisoned from } \\
\text { foods. }\end{array}$ & $39(60)$ & $25(38)^{*}$ & $1(2)$ \\
\hline 2 & $\begin{array}{l}\text { Protecting the diminishing species of plants and animals } \\
\text { will reduce greenhouse effect. }\end{array}$ & $31(48)$ & $33(50.3)^{*}$ & $1(1.7)$ \\
\hline 3 & $\begin{array}{l}\text { The increase in the amount of acid in rains increases } \\
\text { greenhouse effect much more. }\end{array}$ & $40(61.4)$ & $13(20.5)^{*}$ & $12(18.1)$ \\
\hline 4 & $\begin{array}{l}\text { Preventing the usage of nuclear bombs will reduce } \\
\text { greenhouse effect. }\end{array}$ & $50(77.4)$ & $12(18.3)^{*}$ & $3(4.3)$ \\
\hline 5 & $\begin{array}{l}\text { When greenhouse effect increases, mush more floods will } \\
\text { happen. }\end{array}$ & $28(42.7)^{*}$ & $28(43.7)$ & $9(13.6)$ \\
\hline 6 & $\begin{array}{l}\text { The waste thrown away from nuclear power stations } \\
\text { increase greenhouse effect much more. }\end{array}$ & $46(70.0)$ & $4(5.8)^{*}$ & $16(24.2)$ \\
\hline 7 & $\begin{array}{l}\text { The wastes drained to rivers increase greenhouse effect } \\
\text { much more. }\end{array}$ & $24(36.8)^{*}$ & $31(47.2)$ & $10(16.0)$ \\
\hline 8 & $\begin{array}{l}\text { The thinning of ozone layer is defined as non-transmission } \\
\text { of the lights to the atmosphere which are reflected from } \\
\text { crust of the earth. }\end{array}$ & $32(49.6)$ & $20(30.4)^{*}$ & $13(20.0)$ \\
\hline 9 & The thinning of ozone layer increases greenhouse effect. & $44(67.1)$ & $9(14.2))^{*}$ & $12(18.7)$ \\
\hline 10 & Ozone layer protects the world from high temperatures. & $47(71.6)$ & $14(22.2)^{*}$ & $4(6.2)$ \\
\hline 11 & $\begin{array}{l}\text { If ozone layer continues thinning, it will affect the } \\
\text { temperature of the weather and so the weather of our } \\
\text { world will change. }\end{array}$ & $54(83.1)$ & $7(11.3)^{*}$ & $4(5.6)$ \\
\hline 12 & $\begin{array}{l}\text { The glaciers in the poles will be affected by the increase in } \\
\text { the problem of ozone layer depletion. }\end{array}$ & $45(69.5)$ & $12(19.1)^{*}$ & $7(11.4)$ \\
\hline 13 & $\begin{array}{l}\text { Much more lights will get into the world with the increase in } \\
\text { carbon (IV) oxide and so the increase in the amount of light } \\
\text { can't return to the space and this situation will increase the } \\
\text { thinning of ozone layer. }\end{array}$ & $45(68.5)$ & $13(20.1)^{*}$ & $7(11.4)$ \\
\hline 14 & $\begin{array}{l}\text { Reducing nuclear weapons stocks also reduce global } \\
\text { warming. }\end{array}$ & $38(59.0)$ & $17(25.9)^{*}$ & $10(15.1)$ \\
\hline 15 & $\begin{array}{l}\text { The hole in ozone layer is the main reason of global } \\
\text { warming. }\end{array}$ & $39(60.2)$ & $16(24.7)^{\star}$ & $10(15.1)$ \\
\hline 16 & $\begin{array}{l}\text { Increase in ultraviolet rays will also increase the thinning of } \\
\text { ozone layer. }\end{array}$ & $41(62.5)$ & $13(19.7)^{\star}$ & $12(17.8)$ \\
\hline 17 & $\begin{array}{l}\text { The wastes thrown away from nuclear stations damage } \\
\text { ozone layer. }\end{array}$ & $36(54.7)$ & $19(29.4)^{*}$ & $10(15.9)$ \\
\hline
\end{tabular}


“*'means that it is the right answer for the statement. The table also indicates that $49.6 \%$ of the preservice biology teachers defined ozone layer as transmission of the lights to the atmosphere which are reflected from the crust of the earth. Whereas $67.1 \%$ of them had the misconception that the thinning of ozone layer increase greenhouse effect, about $71.6 \%$ of the preservice teachers had the misconception that ozone layer protects the world from being very hot. Furthermore, $62.5 \%$ of them misconceived that increase in ultraviolet rays will increase the hole in ozone layer, while $83.1 / \%$ of them had a wrong opinion that the increase in the thinning of ozone layer will affect the temperature of the weather which will subsequently change the weather of the world. The glaciers in the poles will not be affected by the increase in the problem of ozone layer depletion, but $69.5 \%$ misconceived that the glaciers in the poles will be affected by the increase in the problem of ozone layer. Much more lights will not get into the world with the increase in carbon (IV) oxide and this situation will not increase the thinning of ozone layer but in contrary, about $68.5 \%$ of the preservice biology teachers had the misconception that much more lights will get into the world with the increase in carbon (IV) oxide and so the growing amount of lights can't return to the space and this situation will increase the thinning of ozone layer. It was also found that $60.2 \%$ of them had the misconception that the hole in the ozone layer is the main reason of global warming, whereas the hole in the ozone layer is not the main reason of global warming.

The wastes thrown out of nuclear stations do not damage ozone layer but it was also found out that $54.7 \%$ of the respondents had the misconception that the wastes thrown out of nuclear stations damage ozone layer. Finally, Also $59 \%$ of the pre-service biology teachers in this study had the misconception that reducing nuclear weapons stocks also reduces global warming, whereas reducing nuclear weapons stocks would not reduce global warming.

\section{DISCUSSING AND CONCLUSION}

The findings in this study showed that the preservice biology teachers had misconceptions on some environmental phenomena such as global warming, greenhouse effect and ozone layer depletion. These three concepts were interchangeably used by the respondents. They had misconception that the resultant effect of ozone layer depletion would subsequently increase greenhouse effect. The respondents misconceived the hole in ozone layer as the main reason of global warming. The finding in this study is in agreement with those of Wiesenmayer (1999), Darcin, Bozkurt, Hamalosmanoglu, and Kose (2006), Kalipit, et al (2009) and Etobro \& Osokoya (2013).

The study further revealed that the pre-service biology teachers in the university have a lot of misconceptions such as the glaciers in the poles will be affected by the increase in the problem of ozone layer; the hole in the ozone layer is the main reason of global warming; reducing nuclear weapons stocks also reduces global warming; and that much more lights will get into the world with the increase in carbon (IV) oxide and so the growing amount of lights can't return to the space and this situation will increase the thinning of ozone layer. The finding is also in consonant with those of Khalid (2003), Jefferies, Stanisstreet \& Boyes (2004), Ekborg \& Arekoug (2006) and Etobro \& Osokoya (2013); who reported many misconceptions concerning the greenhouse effect, the ozone layer depletion and acidification among pre-service teachers. The implication of these misconceptions among these pre-service biology teachers is that such misconceptions will be transmitted to their students when they become practicing teachers and that this confusion might continue in the next generations. Majority of the pre-service biology teachers had misconceptions on global warming, ozone layer depletion and greenhouse effect. It is imperative, therefore to proffer solutions to these misconceptions held by the pre-service teachers by ensuring that instructors and instructional materials emphasize the importance of these concepts to life ensuring that students have adequate knowledge about the concepts as well as ways of tackling these challenges. The concepts and issues about environmental education programmes should be explained with tangible examples and creating an active teaching atmosphere to prevent pre-service biology teachers from falling into misconception. In-service training should be provided to practicing teachers to dispel misconceptions from their minds. 


\section{REFERENCES}

Andersson, B and A. Wallin, 2000 'Student understanding of the greenhouse effect social consequences of reducing $\mathrm{CO}_{2}$ Emission and why ozone layer depletion is a problem $\mathrm{J}$ Research In Sci. Teaching. 37(10):1096-11111.

Boyes, E., Chambers, M. and Stanisstreet, M., 1955 'Trainee Primary Teacher' Idea about the Ozone Layer'. Environ. Edu. Res. 1.

Darcin, E. S, O. Dozkurt, M. Hamalsomanoglu and S. Kose, 2006 'Determination of elementary students' level of knowledge and misconception about greenhouse effect'. Intel J. Environ Sci. Education 1(2)104-115.

Ekborg, M. and Areskoug, 2006. 'How students teachers' understanding of greenhouse effect develops during a teacher education programme'. Nordian, 5:17-29.

Goel, A. and Bhatt, R., 2012.Causes and consequences of global warming. International Journal Life Science, Bt \& Pharm. Res. Vol. 1(1).

Jeffries, H., Stanistreet, M. And Boyes, E., 2004. Knowledge about the greenhouse effect: Have college students improved? Research In Sci. Techin. Edu. 19(2): 200-221.
Kalipit, E., Yener, Y. and Ozakadif, S., 2009. The opinions of teacher candidates about global warming, greenhouse effect and ozone layer. World Applied Science Journal 7(1): 67-75.

Khalid, T., 2003. Pre-service high school teachers' perceptions of three environmental phenomena. Environ. Edu. Res. Technol., 8.

Rye, J., Ruba, R. and Wiese mayer, R. and Wiesenmayer, R., 1997. 'An investigation of middle school student alternative conception of global warming as formative evaluation of teachersdeveloped STS Units'. International Journal of Science Education. 19(5).

UNEP, 1993. Handbook on the montrel protocol on substance that deplete the ozone layer. United Nations Environmental Programme, Nairobi.

Umair Shahzad, Riphah, U. S., 2015. Global Warming: Causes, Effects and Solutions Durreesamin Journal, Vol. 1 (4).

United States Environmental Project Agency 2010. 'Ozone Layer Depletion'. www.epa.gov/ozone/strathome.html retrieved on 25th August,2017

Yener, D and E. Kalipet, 2017 ' A survey study on environmental knowledge of education faculty students .J. Intl Environ Appk Scum 2(3and4): 71-78. 